\title{
Settlement, growth, and movement of silver hake Merluccius bilinearis in nursery habitat on the New York Bight continental shelf
}

\author{
Brian P. Steves ${ }^{1,2, *}$, Robert K. Cowen ${ }^{1,3}$ \\ ${ }^{1}$ Marine Sciences Research Center, State University of New York at Stony Brook, Stony Brook, New York 11794-5000, USA \\ ${ }^{2}$ Smithsonian Environmental Research Center, PO Box 28, 647 Contees Wharf Rd., Edgewater, Maryland 21037, USA \\ ${ }^{3}$ Division of Marine Biology and Fisheries, Rosenstiel School of Marine and Atmospheric Science, University of Miami, \\ 4600 Rickenbacker Causeway, Miami, Florida 33149, USA
}

\begin{abstract}
Silver hake Merluccius bilinearis from the New York Bight were examined for the quality and quantity of their offshore settlement and nursery habitats. Juveniles were collected during 10 cruises between June 1996 and July 1997 using a $2 \mathrm{~m}$ beam trawl. Settlement began in July 1996 and peaked in September and October 1996 on the outer shelf $\left(47\right.$ to $95 \mathrm{~m} ; 8$ to $\left.10^{\circ} \mathrm{C}\right)$. Otolith analysis of fish collected during peak settlement was used to calculate the mean age and length at settlement, $34.5 \mathrm{~d}$ and $15 \mathrm{~mm}$, and pre- and post-settlement growth rates, 0.35 and $0.51 \mathrm{~mm} \mathrm{~d}^{-1}$, respectively. Back calculated settlement dates suggest that peak settlement is tied to the lunar cycle. Post-settlement growth rates along a temperature gradient $\left(8\right.$ to $\left.12^{\circ} \mathrm{C}\right)$ indicate that silver hake in areas of cooler bottom temperatures $\left(\sim 9^{\circ} \mathrm{C}\right)$ were not only larger and more abundant, but also faster growing. Movements of early juveniles imply that settlement habitat is more specific than juvenile nursery habitat. Overall, the outer portion ( 60 to $95 \mathrm{~m}$ ) of the continental shelf serves as important nursery habitat for silver hake.
\end{abstract}

KEY WORDS: Habitat - Juvenile · Nursery · Growth - Distribution · Otolith · Merluccius bilinearis

\section{INTRODUCTION}

Knowledge of the dynamics of mechanisms operating during the early life history of fish is considered essential to the understanding of interannual recruitment variability (Sissenwine 1984, Houde 1987, Bradford 1992). As fish develop, they often pass through several different habitats. Small-scale variations within stage-specific habitats, such as nursery grounds, may impart benefits to those fish that manage to utilize areas of greater than average quality (Sogard 1992, Gibson 1994). Increased nursery habitat quality is associated with those areas in which growth, survival, and fitness are optimized (Gibson 1994). Thus, habitat quality can be measured in terms of realized growth.

\footnotetext{
•E-mail: steves@serc.si.edu
}

Factors which describe the quality of fish habitats are varied and include temperature, salinity, dissolved oxygen, current regime, habitat structure, the abundance of prey items, and presence of predators (Gibson 1994). Of the abiotic factors listed here, temperature, due to its direct influence on metabolism, may have the most influence in determining habitat quality for many marine fishes (Neill et al. 1994). Differences in growth rates along an environmental gradient, such as temperature, have been used as a method to indirectly examine the quality of habitats (Sogard 1992, Jenkins et al. 1993).

The continental shelf of the New York Bight (NYB) acts as important settlement and nursery grounds for many species of demersal fish in the northwestern Atlantic (Steves et al. 1999). The shelf as a nursery provides a wide variety of environments ranging in depth from 0 to $200 \mathrm{~m}$, with bottom temperatures from 0 to 
$25^{\circ} \mathrm{C}$ and bottom salinities from 29 to $36 \%$. Intraspecific habitat preferences, however, are often limited to a specific subset of these ranges (Steves et al, 1999). For example, Steves et al. (1999) found post-settlement juveniles of the yellowtail flounder Pleuronectes ferrugineaus to be limited to areas mid-shelf where bottom temperatures are consistently between 4 and $8^{\circ} \mathrm{C}$ during the summer months. Other species, such as o-group (i.e. young-of-the-year) silver hake Merluccius bilinearis are distributed over a broad temperature range $\left(8\right.$ to $19^{\circ} \mathrm{C}$ ), and are consequently exposed to potentially high variation in habitat quality (Auster et al. 1997, Steves et al. 1999).

Silver hake are an important commercial groundfish with a wide distribution on the continental shelf along the east coast of the United States and Canada (Bigelow \& Schroeder 1953). Spawning of silver hake is protracted, with up to 3 spawning events within a season, beginning in May and extending to November. Peak spawning is variable between years, having been noted to occur on the outer shelf (54 to $127 \mathrm{~m}$ ) in June of 1966 (Fahay 1974) and in August of 1977-79 (Sherman et al. 1984). Silver hake larvae hatch at ca 2.6 to $3.5 \mathrm{~mm}$ and are reported to spend ca $60 \mathrm{~d}$ in the plankton before settling to the bottom between 17 and $20 \mathrm{~mm}$ (Fahay 1974). In the NYB, silver hake larvae are an important constituent of the summer ichthyoplankton on the outer shelf (Kendall \& Naplin 1981, Cowen

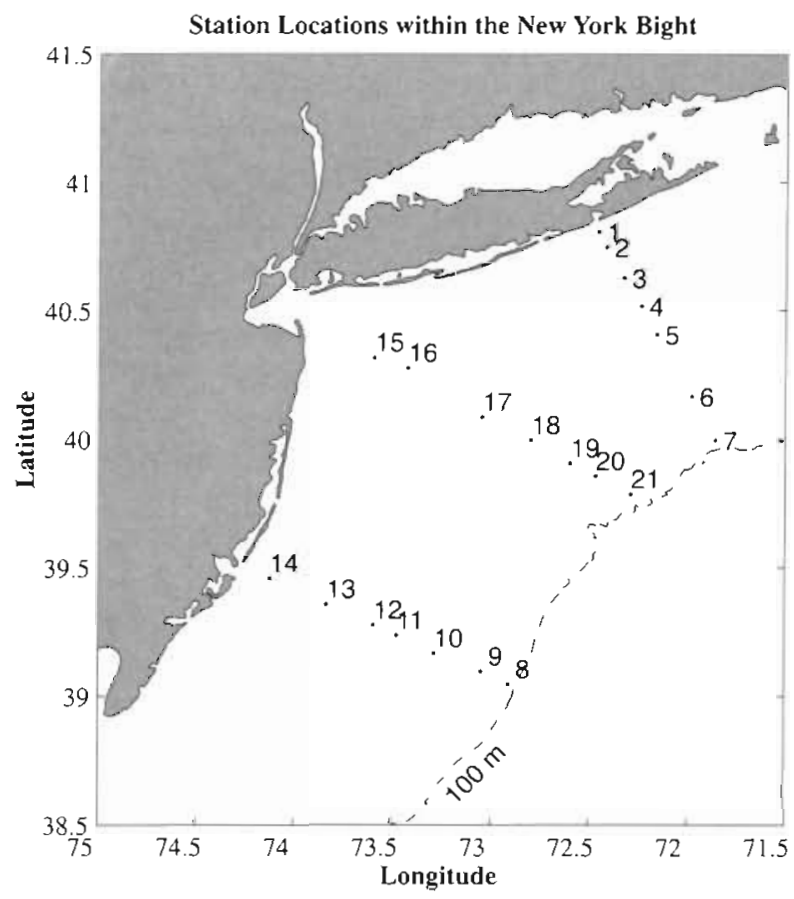

Fig. 1. Map of the New York Bight noting the location of the 21 stations (in 3 transects) sampled each cruise. The offshore boundary represents the $100 \mathrm{~m}$ isobath et al. 1993). Once on the bottom, 0-group silver hake may be associated with the presence of amphipod tube mats (Auster et al. 1997); however little else is known about this potentially important life history stage. For example, although otoliths from 0-group silver hake were among the first to show that daily increments occur in temperate fishes (Panella 1971), no significant work has been done since utilizing their otolith microstructure.

This paper examines the size and age at settlement, distribution, and post-settlement growth of 0-group silver hake on the continental shelf of the NYB. Differences in post-settlement growth rates, abundance, and size across a temperature and depth gradient are used to estimate habitat quality for this species. This information will contribute to the identification of essential nursery habitat for juveniles of this commercially important species.

\section{MATERIALS AND METHODS}

The collection of 0 -group silver hake and associated environmental data is described in detail in Steves et al. (1999). Briefly, a total of ten $3 \mathrm{~d}$ cruises were undertaken approximately monthly in the NYB from June 1996 to July 1997. All fish were collected with a $2 \mathrm{~m}$ beam trawl with a $4 \mathrm{~mm}$ stretch mesh net. At each of the 21 stations (Fig. 1), 3 to 5 replicate 5 min tows were made. All 0-group fish were sorted on deck and preserved in $95 \%$ ethanol. A meter wheel on the trawl allowed the determination of area swept during each tow. Temperature and salinity were measured using an internal recording CTD at each station.

Growth rates for post-settlement silver hake were calculated by 3 different methods. The simplest approach was to follow the size-frequency distributions across months and divide the change in the size of the mode with the elapsed time (days) between sampling dates. The second and third methods of growth determination utilized information obtained from the analysis of otolith microstructure. One method integrated growth from age-at-length over the life of the fish and the other estimated the daily somatic growth from otolith increment widths.

Fish were measured to the nearest $0.1 \mathrm{~mm}$ standard length (SL) using digital calipers. Because $50 \%$ of silver hake in the study area sexually mature in their second year of life at approximately $220 \mathrm{~mm}$ SL (NEFSC 1993), only fish less than $200 \mathrm{~mm}$ were considered to be juveniles. Size-frequency distributions of the juvenile silver hake were created for each cruise. The vast majority of juvenile hake were collected in September and October and these length distributions were further analyzed between cruises and among bottom tem- 
peratures and depths for the stations. The occurrence of a bimodal size-frequency distribution in October required that the 2 modes be separated using the log-likelihood method (MacDonald \& Pitcher 1979). Because the single mode in September and the 2 modes in October were skewed, the modal analysis was conducted on log-transformed SLs with the results being back transformed and plotted.

Otolith microstructure was analyzed on a subset of the silver hake collected in September and October 1996. For each cruise, fish were sorted into $10 \mathrm{~mm}$ size categories (stanzas) from 15 to $55 \mathrm{~mm}$. Three fish from each stanza were selected at random from each station in which adequate representation of at least 3 stanzas occurred (11 stations in September and 9 stations in October). The right sagitta was extracted, and placed sulcus side up onto a glass slide and embedded in epoxy (West System 105 epoxy resin with 206 hardener). Embedded otoliths were ground with 600 and 1200 grit wet sandpaper along the sagittal plane until the primordium was reached and then polished with $0.3 \mu \mathrm{m}$ aluminum oxide on billiard cloth. Otoliths that cracked or were over ground during this process $(\sim 10 \%)$ were replaced with the left otolith from the pair and the process was repeated. Otoliths were viewed through a video-equipped compond microscope with a $25 x$ oil immersion objective and a $10 x$ ocular lens.

Image enhancement and analysis was conducted using Optimas 6.1 (Optimas Corp, Bothell, WA) and triplicate increment counts were made for each sagitta. Otoliths in which the 3 increment counts did not agree within $10 \%$ were discarded. Mean increment count for each otolith was used in all analyses. A total of 153 silver hake sagittae from fish collected in September and October 1996 were used in the analysis, while 21 were discarded. These sagittae ranged in size from 0.51 to $2.71 \mathrm{~mm}$ along the longest axis from fish 16.1 and $53.4 \mathrm{~mm}$, respectively

In some species, the formation of secondary nuclei corresponds to metamorphosis (end of the larval stage), and for benthic species, settlement. This correspondence between secondary nuclei has been identified in members of a range of fish orders including, pleuronectiformes (Sogard 1991, Toole et al. 1993), perciformes (Hare \& Cowen 1995), and gadiformes (Nishimura \& Yamada 1984). Nearly all silver hake otoliths contained increments originating from secondary nuclei, though their presence did not interfere with increment counts. We used the location of the secondary nuclei observed in the hake sagitta to estimate age at metamorphosis and thus settlement. A subsample of 50 otoliths in which a secondary nucleus was clear was used to estimate a mean and confidence limits for the age at settlement. The mean age at settle- ment (i.e. larval duration) was then used to predict a mean size at settlement based on the regression of length versus total increment counts for all otoliths. Pre-settlement growth was estimated as the difference between the reported size at hatching, $-3 \mathrm{~mm}$ SL (Fahay 1974), and estimates of settlement size and larval duration. We are unaware of any work concerning the age at formation of the first increment in silver hake, but laboratory work on Merluccius productus from the Pacific suggests that it ranges from $3 \mathrm{~d}$ at $15^{\circ} \mathrm{C}$ to $8 \mathrm{~d}$ at $8^{\circ} \mathrm{C}$ (Bailey 1982). Larval silver hake in the NYB during late summer are primarily found near the thermocline at temperatures near $17^{\circ} \mathrm{C}$ (Kendall \& Naplin 1981). From this, we assume that increment formation occurs on the third day post hatch; thus $3 \mathrm{~d}$ are added to all increment counts to convert them to days.

Linear regressions of SL and age from the mean settlement age and length were used to determine the mean post-settlement growth rates during each cruise. Individual post-settlement growth rates were similarly calculated in reference to this settlement point. Analysis of the homogeneity of regression slopes was used to determine any differences in growth rates among cruises. Because growth rates in juvenile fish often vary with size, in addition to an ANOVA of growth rates among temperatures, an analysis of covariance (ANCOVA) with standard length as the covariate was used to test whether growth rates varied among temperatures.

Since the temperatures experienced by juvenile silver hake could change throughout this study, we chose to examine the growth/temperature relationship for recent growth (i.e. $10 \mathrm{~d}$ prior to capture; Suthers et al. 1989, Hovenkamp 1990). For this analysis, growth was measured from the same silver hake otoliths using increment widths. First, the otolith to fish length relationship was verified by comparing the standard length of each fish to the radial length of its otolith from the primordium to the rostrum. Individual increment widths were then measured along this radius and converted to increases in fish length based on this relationship. Growth of each fish over the last $10 \mathrm{~d}$ prior to capture were calculated from the mean equivalent increase in fish size from the last 10 increments. The results of individual recent growth were then subjected to the same ANCOVA design as in the first otolith analysis. SL was treated as a covariable and growth rates among groups (based on bottom temperatures at the time of collection) were compared

Based on the above estimates of growth we examined the age-specific distribution of individuals across the continental shelf. For this we separated all fish into $10 \mathrm{~d}$ age classes and contoured their abundance across sampling stations by date. These distributions are compared to determine changes in settlement habitat 
with time as well as movements of silver hake between settlement and nursery habitats.

\section{RESULTS}

\section{Hydrography}

Cross shelf temperatures within the NYB changed dramatically between summer and early fall. During the 3 cruises from June to August 1996, the water column was characterized by strong thermal stratification. Also present at this time was the cold pool, a large mass of cold water $\left(<6\right.$ to $\left.8^{\circ} \mathrm{C}\right)$ mid-shelf between the 40 and $70 \mathrm{~m}$ isobath (Fig. 2). For the cruises in late September and October 1996, the hydrography displayed neither the strong thermal stratification nor the presence of the cold pool as it did earlier in the summer. The area of minimum bottom temperature was greater than $8^{\circ} \mathrm{C}$ in the fall and was found on the outer shelf, with temperatures gradually increasing towards shore (Fig. 2). The transition between a stratified and an unstratified water column (i.e. turnover) occurred sometime between the August and September cruises. After turnover, isothermic water temperatures continued to decrease until April followed by thermal stratification by June 1997 due to vernal warming of surface waters.

\section{Seasonal abundance and size}

Juvenile silver hake (i.e. less than $200 \mathrm{~mm}$ SL) were collected in 9 of the 10 cruises from 3 distinct age classes. In June and July 1996 several larger juvenile hake were collected, presumably from the previous year's cohort (Fig. 3, Table 1). Newly settled juvenile silver hake were first collected during the 10 to 12 July 1996 cruise ( 3 individuals, 16.5 to $17.5 \mathrm{~mm} \mathrm{SL}$ ). A single 0-group silver hake (17.9 mm SL) was obtained on 9 August 1996. For the 20 to 22 September 1996 cruise the abundance of 0 -group silver hake reached its highest level at a mean of 87.0 fish per $1000 \mathrm{~m}^{2}$ (total $\mathrm{n}=$ 2559). The length-frequency distribution of measured silver hake SLs during the September cruise was unimodal with a mode of $22 \mathrm{~mm}$ and a range from 12.9 to

\section{Bottom Temperatures $\left({ }^{\circ} \mathrm{C}\right)$}
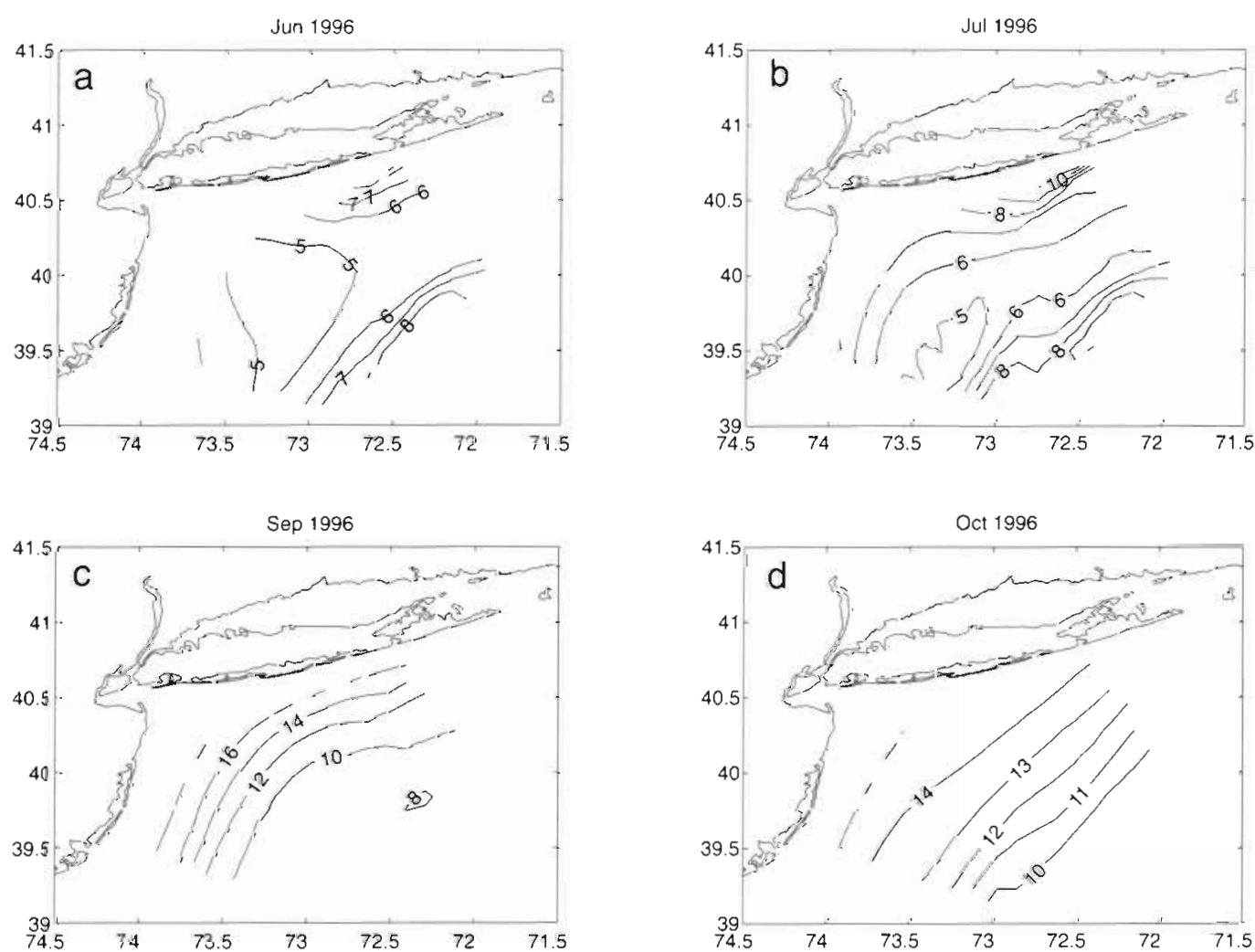

Fig. 2. Contour plots of bottom temperatures $\left({ }^{\circ} \mathrm{C}\right.$ ) for (a) June, (b) July, (c) September, and (d) October. The outlines of Long Island (to the north) and New Jersey (to the west) are plotted for reference 


\section{Length Frequency Distributions by Cruise}
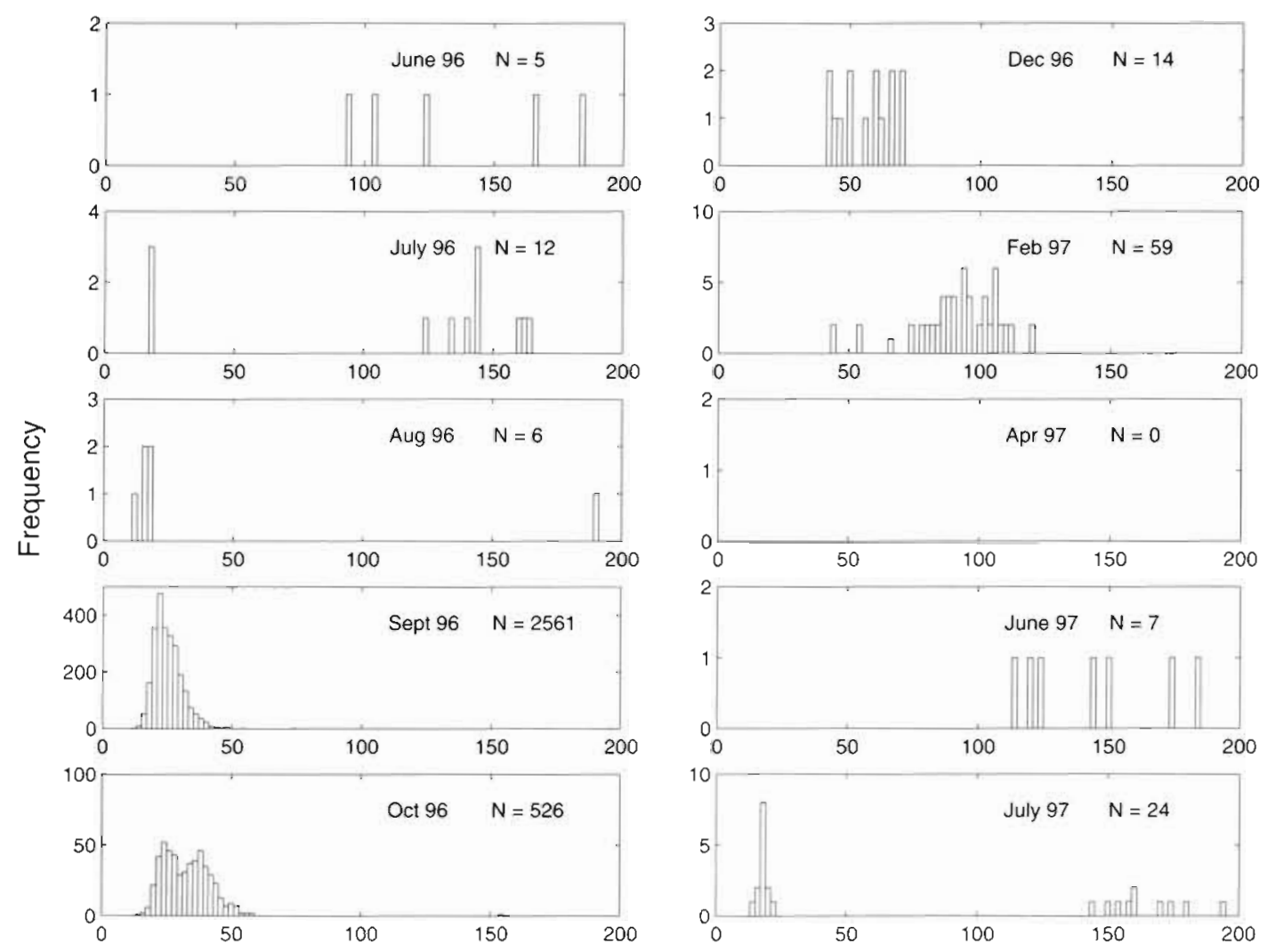

Standard Length $(\mathrm{mm})$

Fig. 3. Length frequency histograms for all silver hake collected during the 10 cruises between June 1996 and July 1997 . Of partıcular interest, September had a unimodal distribution with a mode at $22 \mathrm{~mm}$ standard length, while October had a bimodal distribution at 24 and $38 \mathrm{~mm}$ standard length

$54 \mathrm{~mm}$ SL. During the October cruise, abundance of 0 -group silver hake was lower with 18.1 fish per $1000 \mathrm{~m}^{2}$ (total $\mathrm{n}=523$ ). The fish caught in October ranged in size from 13.5 to $57.5 \mathrm{~mm}$ SL, but unlike September, the length-frequency distribution was bimodal (modes at $24 \mathrm{~mm} \mathrm{SL}, \mathrm{n}=245$ and $38 \mathrm{~mm} \mathrm{SL}, \mathrm{n}=278$ ). The difference between the second mode in October (38 $\mathrm{mm}$ SL) and the single mode in September $22 \mathrm{~mm}$ $\mathrm{SL}$ ) was $16 \mathrm{~mm}$ in $32 \mathrm{~d}$. Assuming these modes represent the same cohort, estimated growth rate of this group is about $0.5 \mathrm{~mm} \mathrm{~d}^{-1}$. For both the September and October cruises, greater than $89 \%$ of all 0 -group silver hake were collected in the outer half of the continental shelf between 60 and $95 \mathrm{~m}$ in depth (Table 1). Samples from stations further offshore in cooler waters not only contained more silver hake, but also slightly larger individuals during both cruises, although this relationship was strongest for the September cruise (Table 2).

After the October cruise, collection of juvenile silver hake diminished greatly. A total of only 104 silver hake under $200 \mathrm{~mm}$ were collected during the remaining 5 cruises. With the exception of 14 hake collected in July 1997 that were less than $30 \mathrm{~mm}$ SL, these hake were larger than those at near settlement during September and October. Despite low numbers, the size frequency distributions for these later cruises show these large juvenile hake to be the growing members of the previous fall's cohort, but with such low numbers, the distinction between the September and October cohorts is not apparent. Analysis of the mean size of these larger juveniles with time gives an approximate growth rate of ca $0.4 \mathrm{~mm} \mathrm{mo}^{-1}$. Interestingly, no juvenile hake (less than $200 \mathrm{~mm} \mathrm{SL}$ ) were collected during the April 1997 cruise (Fig. 3).

\section{Settlement and growth}

The age at settlement determined from pre-secondary nuclei counts and corrected for age at first in- 
Table 1. Mean and standard deviation (SD) of standard length (mm) and depth (m) of collection for each of the 3 settlement cohorts collected over the course of the 10 cruises. Cohorts are named after the year in which they first settled to the bottom. 15 See

Fig. 3 for length frequency distributions related to this table and note that the 1996 cohort in October contained 2 modes

\begin{tabular}{|c|c|c|c|c|c|c|c|c|c|c|c|}
\hline \multirow[t]{2}{*}{ Cruise } & \multirow[t]{2}{*}{ Date } & \multirow[t]{2}{*}{ Day } & \multicolumn{3}{|c|}{1995 Cohort } & \multicolumn{3}{|c|}{1996 Cohort } & \multicolumn{3}{|c|}{1997 Cohort } \\
\hline & & & $\mathrm{N}$ & Mean & $\mathrm{SD}$ & $N$ & Mean & $\mathrm{SD}$ & $\mathrm{N}$ & Mean & SD \\
\hline \multicolumn{12}{|c|}{ Standard length $(\mathrm{mm})$} \\
\hline 1 & 14 Jun 96 & 0 & 5 & 135.2 & 39.4 & 0 & - & - & 0 & - & - \\
\hline 2 & 09 Jul 96 & 25 & 9 & 147 & 13.407 & 3 & 17.83 & 0.779 & 0 & - & - \\
\hline 3 & 09 Aug 96 & 56 & 1 & 190 & 0 & 5 & 16.224 & 2.11 & 0 & - & - \\
\hline 4 & 20 Sep 96 & 98 & 0 & - & - & 2560 & 25.1 & 5.31 & 0 & - & - \\
\hline 5 & 25 Oct 96 & 133 & 0 & - & - & 525 & 31.81 & 8.73 & 0 & - & - \\
\hline 6 & 10 Dec 96 & 1.79 & 0 & - & - & 14 & 56.57 & 9.98 & 0 & - & \\
\hline 7 & 26 Feb 97 & 257 & 0 & - & - & 59 & 92.13 & 16.48 & 0 & - & - \\
\hline 8 & 16 Apr 97 & 306 & 0 & - & - & 0 & - & - & 0 & - & - \\
\hline 9 & 11 Jun 97 & 362 & 0 & - & - & 7 & 145 & 24.23 & 0 & - & - \\
\hline 10 & $15 \mathrm{Jul} 97$ & 396 & 0 & - & - & 10 & 164.8 & 15.18 & 14 & 17.86 & 1.82 \\
\hline \multicolumn{12}{|c|}{ Depth (m) } \\
\hline 1 & 14 Jun 96 & 0 & 5 & 49.4 & 12.4 & 0 & - & - & 0 & - & - \\
\hline 2 & 09 Jul 96 & 25 & 9 & 50.4 & 8.9 & 3 & 75.3 & 25.4 & 0 & - & - \\
\hline 3 & 09 Aug 96 & 56 & 1 & 35 & 0 & 5 & 40.4 & 13.1 & 0 & - & - \\
\hline 4 & 20 Sep 96 & 98 & 0 & - & - & 2560 & 80.7 & 14.6 & 0 & - & - \\
\hline 5 & 25 Oct 96 & 133 & 0 & - & - & 525 & 67.0 & 12.9 & 0 & - & - \\
\hline 6 & $10 \operatorname{Dec} 96$ & 179 & 0 & - & - & 14 & 40.1 & 14.9 & 0 & - & - \\
\hline 7 & 26 Feb 97 & 257 & 0 & - & - & 59 & 39.4 & 10.7 & 0 & - & - \\
\hline 8 & 16 Apr 97 & 306 & 0 & - & - & 0 & - & - & 0 & - & - \\
\hline 9 & 11 Jun 97 & 362 & 0 & - & - & 7 & 48.4 & 10.9 & 0 & - & - \\
\hline 10 & $15 \mathrm{Jul} 97$ & 396 & 0 & - & - & 10 & 39.6 & 17.6 & 14 & 63.2 & 22.5 \\
\hline
\end{tabular}

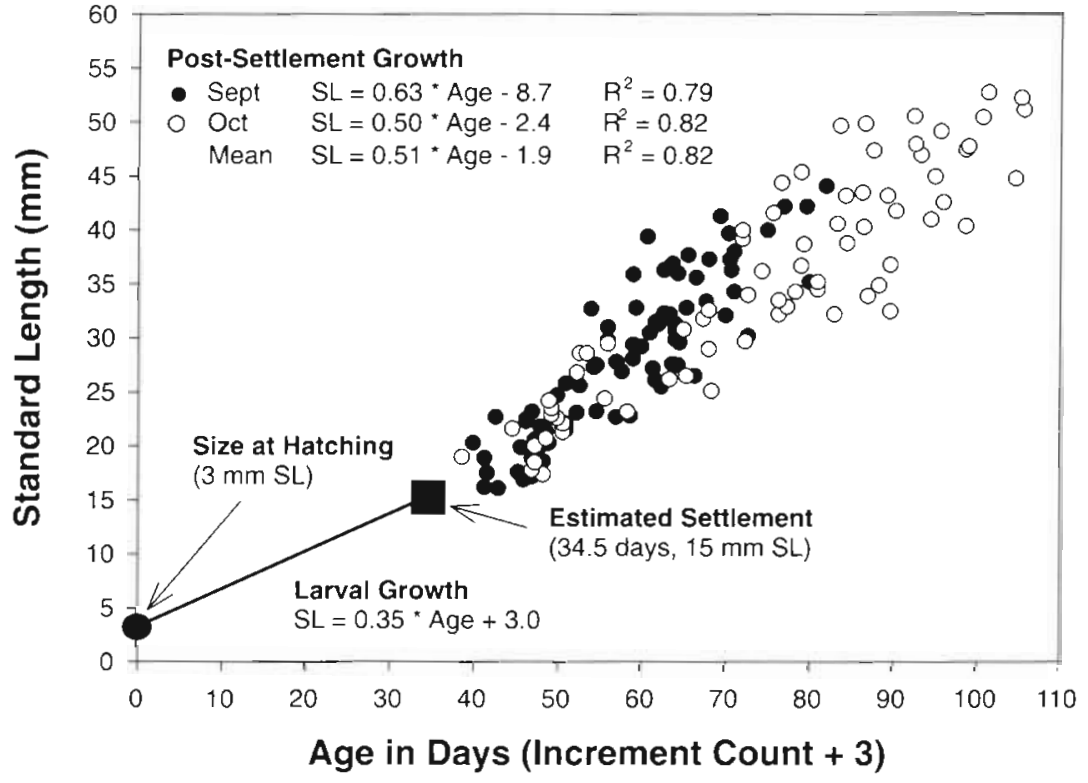

Fig. 4. Overall length-at-age regression for the September and October 1.996 collections of silver hake in the New York Bight. Growth is divided between pre- and postsettlement life history stages. Regressions are included for each cruise as well as both cruises combined crement formation was estimated at $34.5 \pm 0.52 \mathrm{~d}$ (mean and $95 \%$ confidence intervals). This corresponds to a settlement size of ca $15 \mathrm{~mm}$ SL based on the regression of SL to age (Fig. 4). Furthermore, many of the smallest fish ( 16 to $20 \mathrm{~mm}$ ) examined had secondary growth that contained less than 10 increments past secondary nuclei. Such early development of these secondary nuclei and the fact that these otoliths came from the very smallest fish collected on the bottom $(-15 \mathrm{~mm})$ indicate that these otoliths are likely representative of recently settled fish.

Total increment counts for all otoliths ranged from 36 to 102 for fish measuring between 16.1 and $52.8 \mathrm{~mm}$ $\mathrm{SL}$. The regression of SL on increment count (age) for 
both cruises combined had a slope of $0.51 \mathrm{~mm} \mathrm{~d}^{-1}$ (Fig. 4) which represents the mean post-settlement growth for September and October. A pre-settlement or larval growth rate of $0.35 \mathrm{~mm} \mathrm{~d}^{-1}$ was estimated from the difference in size and age between hatching and settling. For individual cruises, average post-settlement growth (Fig. 4) was higher for the September cruise $\left(0.63 \mathrm{~mm} \mathrm{~d}^{-1}\right)$ in comparison to the October cruise $\left(0.50 \mathrm{~mm} \mathrm{~d}^{-1}\right)$. The difference between slopes of the length at age relationships (growth rates) between cruises was significant $(p=0.008)$. Post-settlement growth rates calculated for individual fish ranged from 0.08 to $0.90 \mathrm{~mm} \mathrm{~d}^{-1}$.

\section{Temperature-dependent growth}

Differences in post-settlement growth rates among temperatures were not significant (ANOVA, $p=$ $0.081)_{i}$ however when SLs were added to the analy-

Table 2. Number of silver hake collected at each station for September and October 1996. See Fig. 1 for station locations. Silver hake abundance is further broken down into $10 \mathrm{~mm}$ size classes between 15 and $55 \mathrm{~mm}$. The distance from shore, depth, and bottom temperature at each station are included. Stations are listed in order of increasing depth

\begin{tabular}{|c|c|c|c|c|c|c|c|c|}
\hline Stn & $\begin{array}{c}\text { Distance } \\
(\mathrm{km})\end{array}$ & $\begin{array}{l}\text { Depth } \\
\text { (m) }\end{array}$ & $\begin{array}{l}\text { Bottom temp } \\
\left({ }^{\circ} \mathrm{C}\right)\end{array}$ & $\begin{array}{c}\text { Total } \\
\text { abundance }\end{array}$ & $\begin{array}{l}15-25 \\
(\mathrm{~mm})\end{array}$ & $\begin{array}{c}25-35 \\
(\mathrm{~mm})\end{array}$ & $\begin{array}{c}35-45 \\
(\mathrm{~mm})\end{array}$ & $\begin{array}{l}45-55 \\
(\mathrm{~mm})\end{array}$ \\
\hline \multicolumn{9}{|c|}{ Sep 1996} \\
\hline 1 & 5.1 & 20 & 17.4 & 0 & & & & \\
\hline 14 & 14.8 & 20 & 195 & 0 & & & & \\
\hline 15 & 15 & 28 & 18.5 & 3 & 3 & & & \\
\hline 16 & 37 & 33 & 16.8 & 2 & 2 & & & \\
\hline 2 & 12.6 & 36 & 165 & 0 & & & & \\
\hline 13 & 42.1 & 36 & 16.8 & 2 & & 2 & & \\
\hline 3 & 27.9 & 47 & 13.4 & 0 & & & & \\
\hline 11 & 75.8 & 47 & 101 & 68 & 55 & 10 & 3 & \\
\hline 12 & 64.5 & 47 & 11.5 & 29 & 11 & 10 & 7 & 1. \\
\hline 17 & 59.3 & 47 & 105 & 30 & 20 & 10 & & \\
\hline 4 & 42.3 & 56 & 116 & 23 & & 23 & & \\
\hline 18 & 77.8 & 56 & 9.3 & 72 & 24 & 41 & 7 & \\
\hline 19 & 90.7 & 61 & 9.4 & 103 & 48 & 49 & 6 & \\
\hline 5 & 56.3 & 62 & 11 & 9 & 2 & 4 & 3 & \\
\hline 10 & 93.9 & 63 & 8.5 & 243 & 67 & 149 & 27 & \\
\hline 6 & 87 & 72 & 9.1 & 148 & 75 & 59 & 13 & 1 \\
\hline 20 & 101.9 & 72 & 8.2 & 240 & 54 & 161 & 24 & 1 \\
\hline 9 & 115.9 & 75 & 9 & 88 & 43 & 40 & 5 & \\
\hline 8 & 129.2 & 90 & 10 & 725 & 551 & 174 & & \\
\hline 7 & 108.4 & 92 & 9.5 & 589 & 393 & 196 & & \\
\hline 21 & 115.8 & 92 & 8 & 207 & 65 & 111 & 29 & 2 \\
\hline \multicolumn{9}{|c|}{ Oct 1996} \\
\hline 1 & 5.1 & 20 & 14.5 & 4 & 4 & & & \\
\hline 14 & 14.8 & 20 & 16.1 & 0 & & & & \\
\hline 15 & 15 & 28 & 15.2 & 0 & & & & \\
\hline 16 & 37 & 33 & 14.8 & 0 & & & & \\
\hline 2 & 126 & 36 & 14 & 1 & 1 & & & \\
\hline 13 & 42.1 & 36 & 14.3 & 1 & & 1 & & \\
\hline 3 & 27.9 & 47 & 134 & 4 & 1 & 1 & 2 & \\
\hline 11. & 75.8 & 47 & 13.1 & 4 & & 1 & 3 & \\
\hline 12 & 645 & 47 & 13.3 & 17 & 2 & 9 & 6 & \\
\hline 17 & 59.3 & 47 & 13.8 & 29 & 3 & 7 & 17 & 2 \\
\hline 4 & 42.3 & 56 & 12.4 & 43 & 9 & 18 & 10 & 6 \\
\hline 18 & 778 & 56 & 12.7 & 17 & 4 & 7 & 4 & 2 \\
\hline 19 & 907 & 61 & 11.7 & 8 & 1 & 1 & 4 & 2 \\
\hline 5 & 563 & 62 & 11.5 & 98 & 28 & 43 & 22 & 5 \\
\hline 10 & 939 & 63 & 12 & 43 & 12 & 19 & 11 & 1 \\
\hline 6 & 87 & 72 & 9.6 & 40 & 3 & 18 & 12 & 7 \\
\hline 20 & 101.9 & 72 & 10.9 & 83 & 24 & 21 & 24 & 14 \\
\hline 9 & 115.9 & 75 & 9.7 & 87 & 21 & 30 & 32 & 4 \\
\hline 8 & 129.2 & 90 & 9.7 & 8 & 1 & 1 & 6 & \\
\hline 7 & 108.4 & 92 & 9.3 & 3 & 1 & 1 & 1 & \\
\hline 21 & 115.8 & 92 & 9.5 & 32 & 2 & 4 & 22 & 4 \\
\hline
\end{tabular}




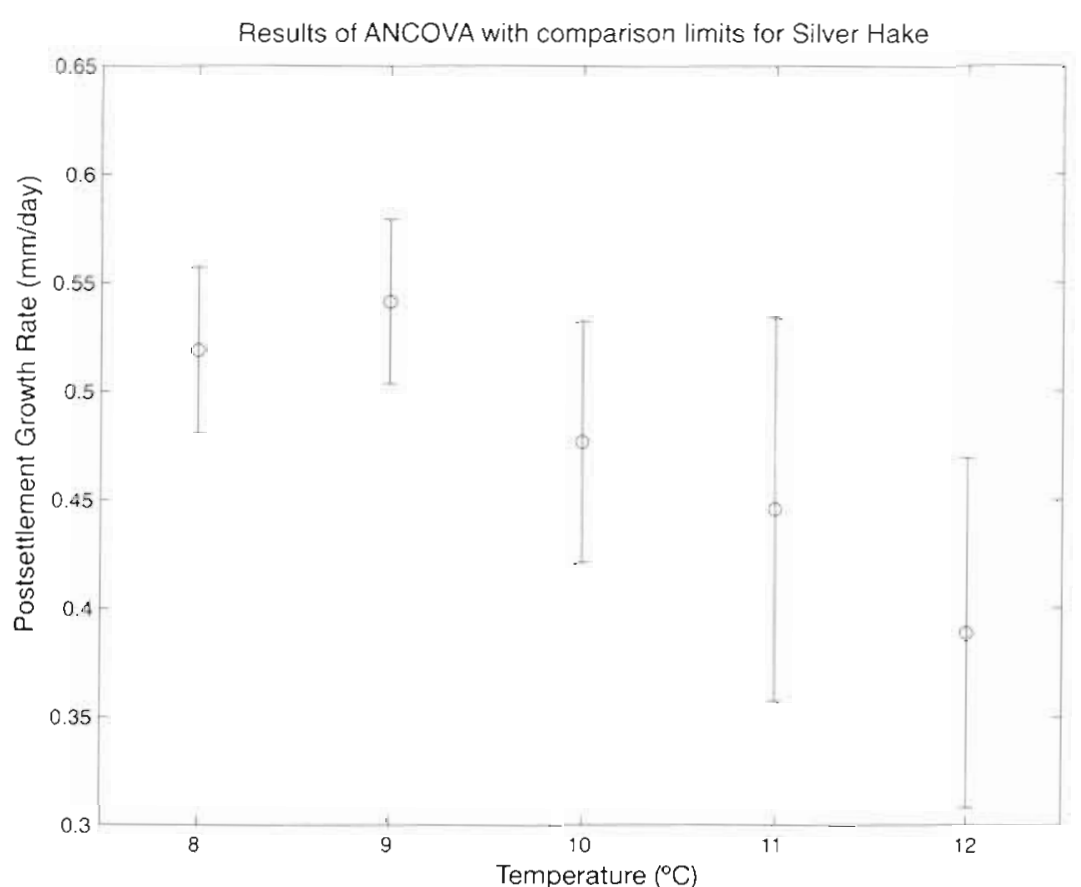

Fig. 5. Adjusted means and 95\% comparison limits from the results of the ANCOVA of post-settlement growth and temperature

lected with mean depths greater than $60 \mathrm{~m}$, while older juveniles were collected with mean depths less than $60 \mathrm{~m}$ (Table 2). The distribution of estimated $10 \mathrm{~d}$ age classes gives an approximate estimate of change in postsettlement distributions. While most silver hake are found in the outer half of the shelf (60 to $95 \mathrm{~m}$ ), the highest concentrations of newly settled silver hake were collected in either 1 or 2 groups on the outer quarter of the shelf (75 to $90 \mathrm{~m}$; Fig. 6) Change in distribution after settlement was gradual. For example, the patterns of distribution among consecutive $10 \mathrm{~d}$ age classes are more similar than those patterns among disjoint age classes. In general, older/larger fish were more broadly distributed than settlement age/size fish both within months and when settlement 'cohorts' are compared between months. For example movement inshore after settlement is evident for the 10 to 20 September cohort between September and October 1996. Our maximum sampling

sis as a covariable, results were significant. The test of the homogeneity among slopes was not significant $(p=0.841)$; thus, differences among the adjusted means could be compared and were significantly different (ANCOVA, $p=0.005$ ). A comparison of individual adjusted means (Fig. 5) did not show any significant differences among groups differing by 1 degree, but a general trend among adjusted means existed with higher growth rates in the cooler temperatures. The large comparison limits about the adjusted mean growth rates for warmer temperatures were the result of the low sample sizes at these temperatures.

For the second otolith analysis using increment widths for the last $10 \mathrm{~d}$ of growth, mean growth rates for all temperature groups were 0.5 to $0.55 \mathrm{~mm} \mathrm{~d}^{-1}$ These growth rates are similar to that of the mean growth rates calculated from both the cohort analysis of the September and October cruises and the otolith analysis of age at length. However, ANCOVA results showed no significant differences in fish growth among temperature groups $(p=0.731)$.

\section{Age-specific distribution}

With the exception of a few very small hake in August 1996, recently settled silver hake were col- depth of $95 \mathrm{~m}$ precluded our ability to determine if migration also occurred offshore.

A comparison of age-specific distributions (Fig. 6) and bottom temperatures for September 1996 (Fig. 2c) show some similarities. The distribution of highest abundance for silver hake, which settled in September (SL 15 to $25 \mathrm{~mm}$ ), is similar to the distribution of $<9^{\circ} \mathrm{C}$ temperatures on the very outer edge of the study area. Larger fish, which settled in August 1996, however, have two areas of peak abundance slightly inshore of the younger fish (Fig. 6). These 2 areas of high abundance correspond to the 2 areas of minimum bottom temperatures $\left(<9^{\circ} \mathrm{C}\right.$ ) on the shelf (Fig. $2 \mathrm{C}$ )

\section{Lunar periodicity}

Estimates of growth from the mode analysis of our size frequency distributions corresponded well with the post-settlement growth estimate of $0.5 \mathrm{~mm} \mathrm{~d}^{-1}$ for fish collected in October from the otolith study. While otolith-based growth rates differed between September and October, the October estimate is used in that it most closely coincides with the growth that occurred between the 2 cruises. Thus the larger mode in October is the same group of fish as in September, with back-calculated settlement dates for this cohort of approximately the 8 to 12 September 1996 (Table 3). 
Distribution of Estimated Settlement Dates
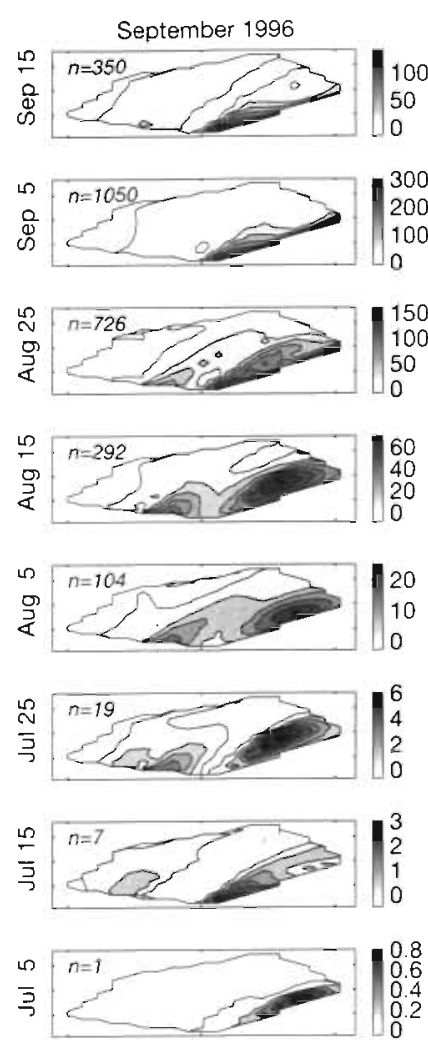

Fig. 6. Age-specific contour plots of the distribution of silver hake for September and October 1996. See map in Fig. 1 for reference to locations within the contours. Age groups are labeled by the estimated date $( \pm 5 \mathrm{~d})$ of settlement onto the shelf based on the standard length of the fish and an estimated growth rate of $0.5 \mathrm{~mm} \mathrm{~d}^{-1}$ Total sample sizes are given in the upper left-hand corner of each subplot. Note that the scale of the contour shading varies among subplots

Furthermore the smaller size class mode in October had a back-calculated settlement date between the 6 and 10 October. The time between settlement dates therefore was $28 \mathrm{~d}$, or about 1 lunar month. In both months, peak settlement occurred on a third quarter moon. Because age at settlement is approximately $35 \mathrm{~d}$ (or 1.25 lunar months), peak spawning for both cohorts would have occurred on full moons.

\section{DISCUSSION}

The minimum size of silver hake $(12.9 \mathrm{~mm}) \mathrm{col}$ lected by our beam trawl with a $4 \mathrm{~mm}$ stretch mesh size, is smaller than the minimum size (17 to $20 \mathrm{~mm}$ ) reported by Fahay (1974) from otter trawl collections with $1 / 4 "(\sim 6.4 \mathrm{~mm})$ mesh. This suggests that silver hake actually begin to settle to the bottom at smaller sizes and therefore sooner than previously thought. One confounding factor to this question concerns the collection of larger individuals (15 to $25 \mathrm{~mm}$ ) in the plankton, particularly at night (Fahay 1974). As suggested by Fahay (1974), after silver hake settle to the bottom, they may continue to migrate vertically at night, presumably to feed. Other gadids, the Atlantic cod Gadus morhua and the haddock Melanogrammus aeglefinus, have been noted to make such nightly feeding excursions in the first couple of months after initial settlement (Lough et al. 1989). For these species, it seems that settlement needs to be better defined. Because we sampled only during the day and pelagic feeding occurs at night, for this study, a change from a completely pelagic existence to one partially demersal (and available to the collection by our trawl) may be considered settlement.

Fahay's (1974) estimated larval duration of 2 mo for silver hake within the NYB was nearly twice that of our estimate $(34.5 \mathrm{~d})$. His calculation was based on the first occurrence of silver hake as yolk sac larvae in June 1966 and the first collection of 17 to $20 \mathrm{~mm}$ individuals in otter trawls in August. Sampling was not conducted in July 1966, suggesting the possibility that an earlier settlement event may have been missed. Alternatively, the early June spawning cohort either had had poor survival and/or settled outside of the NYB.

Our estimates of size and age at settlement at $15 \mathrm{~mm}$ and $34.5 \mathrm{~d}$ are both reasonable considering those reported by other authors for merluccid hakes (Bailey 1982, Woodbury et al. 1995). Larval growth prior to settlement is slightly slower, suggesting that for silver hake settlement to the bottom increases their growth potential. Extensive research regarding the early life history of merluccid hakes has been done on a related species from the Pacific, Merluccius productus. Daily increment formation has been validated for this species using laboratory-reared larvae (Bailey 1982). Growth rates for $M$. productus smaller than $30 \mathrm{~mm}$ are slower than similarly sized $M$. bilinearis $\left(0.2\right.$ vs $\left.0.5 \mathrm{~mm} \mathrm{~d}^{-1}\right)$; however, for juvenile $M$. productus greater than $30 \mathrm{~mm}$, growth rates are similar to or greater than our estimate for $M$. bilinearis (Woodbury et al. 1995). 
Table 3. Estimated settlement dates for Merluccius bilinearis based on a growth rate of $0.5 \mathrm{~mm} \mathrm{~d}^{-1}$, settlement size of $15 \mathrm{~mm}$, and a settlement age of $34.5 \mathrm{~d}$. Modes were selected from the size-frequency histograms of Fig. 3 and growth estimates are shown in Fig. 5

\begin{tabular}{|c|c|c|c|c|c|}
\hline Cruise & Dates & Mode & $\begin{array}{l}\text { Mode size } \\
\quad(\mathrm{mm})\end{array}$ & $\begin{array}{l}\text { Days post- } \\
\text { settlement: }\end{array}$ & $\begin{array}{c}\text { Settlement } \\
\text { date }\end{array}$ \\
\hline Sep & $\begin{array}{l}20 \text { Sep } 96- \\
24 \text { Sep } 96\end{array}$ & I & 22 & 14 & $\begin{array}{l}6 \text { Sep } 96- \\
10 \text { Sep } 96\end{array}$ \\
\hline \multirow[t]{2}{*}{$\mathrm{Oct}$} & $\begin{array}{l}24 \text { Oct } 96- \\
28 \text { Oct } 96\end{array}$ & I & 38 & 46 & $\begin{array}{l}8 \text { Sep } 96- \\
12 \operatorname{Sep} 96\end{array}$ \\
\hline & & II & 24 & 18 & $\begin{array}{l}6 \text { Oct } 96- \\
10 \text { Oct } 96\end{array}$ \\
\hline
\end{tabular}

Snapshots of birthdate-specific spatial distributions in September and October 1996 (Fin. 6) show that across time the mean depth of juvenile hake decreases, distribution spreads more evenly across the outer to middle shelf, and mean size increases, albeit all. at lower densities. In general, it seems that settlement areas are more specific and offshore than juvenile nurseries. This pattern may be explained by 2 non-exclusive mechanisms; inshore migration of juveniles, and increased mortality offshore (possibly density dependent). Migrations

The back-calculation of the modes from the length frequencies gives a general impression to the time of hatching for the majority of the cohort. Individuals from both of these modes were likely to have hatched and settled on similar lunar phases (hatching on waning full moons and settling on waxing new moons). The connection between spawning, settling, and lunar phase is consistent with much of the recruitment data for fish species inhabiting tropical reefs (Sponaugle \& Cowen 1994, Thorrold et al. 1994) and temperate estuaries (Tanaka et al. 1989). However, we know of no other studies that confirm this pattern for any other temperate species inhabiting the continental shelf.

While the increment width study suggested that there were no differences in growth among temperatures, the results of the age at length study suggest that silver hake grew the fastest in cooler waters. Length at age is not representative of recent growth in that it is integrated over a much longer time frame than the increment width study. Nevertheless, decreased growth in warmer waters can also be seen in the difference in the post-settlement growth rates between the September and October cruises. Bottom temperatures were on average a few degrees warmer in October, while growth rates slowed from an average of $0.63 \mathrm{~mm} \mathrm{~d}^{-1}$ in September to $0.50 \mathrm{~mm} \mathrm{~d}^{-1}$ in October. Temperature is not likely to be the sole cause of the variation in growth rates among stations and dates. An interaction between temperature and food availability may be able to explain the potential benefits of cooler temperatures for increased growth (Suthers et al. 1989, Jenkins et al. 1993). One important food source for 0-group silver hake is small crustaceans such as amphipods (Koeller et al. 1989). Auster et al. (1997) suggests that amphipod tube mats serve an important role in microscale habitat selection for silver hake. The peak abundance of the tube-dwelling amphipod Unciola irrorata within the NYB is at a depth greater than $60 \mathrm{~m}$ (Pearce et al. 1981), corresponding well to the areas of higher abundance and growth, and lower temperatures. across depths have been noted among other species such as the Dover sole Microstomus pacificus, which undertakes a migration inshore after settlement (Toole et al. 1997). As shown above, inshore habitats in this study coincided with lower growth rates. Movements of fish into new habitats of potentially lesser quality are known to occur either as a result of advection (Suthers et al. 1989) or density-dependent pressure in which the population range increased into inferior habitat as population size increased (MacCall 1990). Suthers et al. (1989) found that juvenile cod in southwestern Nova Scotia grow best on an offshore bank, while those juveniles advected inshore suffered inferior growth, most likely due to decreased food abundance. Their findings differ from what we observed with silver hake, in that the hake were distributed across a gradual change in habitat (i.e. temperature, depth, and food availability) along the shelf. We cannot at this time determine whether the expansion of the juvenile hake is due to density-dependent habitat selection (sensu MacCall 1990) or density-dependent mortality; however, the result of an expanding distribution is that some juveniles end up in habitat of poorer quality. The overall impact on recruitment success of expanding into lower habitat quality, however, may be minor. In fact, the quantity of suitable habitat can be more important to recruitment success than the presence of superior quality habitat (Gibson 1994).

We conclude that the outer shelf is important habitat for 0-group silver hake. Abundance and growth are both higher in the cooler waters of the outer shelf, implying that this area is not only the preferred habitat, but also better quality habitat for silver hake. Furthermore, migrations of older/larger fish into broader areas of the shelf suggest that nursery habitats are less restrictive for silver hake than settlement areas. September seems to be the prime month for silver hake to settle onto the shelf, with higher abundance and growth rates than October. In summary, bottom temperatures between 8 and $10^{\circ} \mathrm{C}$ and depths between 60 
and $100 \mathrm{~m}$ appear to be the best descriptors of the nursery habitat for 0-group silver hake in the NYB. This work provides further evidence that portions of the continental shelf (in addition to estuaries) should be considered as essential habitat for a variety of species of juvenile fish.

Acknowledgements. We thank all those who have contributed to the various aspects of this work. The fieldwork was made possible with the help of numerous volunteers, particularly Mark Sullivan, Mark Malchoff and Teresa Rotunno. Captain Mark Phillips and the crew of the FV 'Illusion' gave much to the practical aspects of the cruises. This manuscript benefited from critical reviews from Tom Grothues, Ken Able, and Robert Cerrato. This paper resulted from research sponsored by the National Oceanic and A.tmospheric Administration's Saltonstall-Kennedy program, award number NA66FD0012. The views expressed herein are those of the authors and do not necessarily reflect the views of NOAA or its sub-agencies. This is contribution 1185 of the Marine Sciences Research Center.

\section{LITERATURE CITED}

Auster PJ, Malatesta RJ, Donaldson CLS (1997) Distributional responses to small-scale habitat variability by early juvenile siver hake, Merluccius bilinearis. Envrion Biol Fishes 50:195-200

Bailey KM (1982) The early life history of Pacific hake, Merluccius productus. Fish Bull US 80:589-598

Bigelow HB, Schroeder WC (1953) Fishes of the Gulf of Maine. Fish Bull US 53:1-577

Bradford MJ (1992) Precision of recruitment predictions from early life stages of marine fishes. Fish Bull US 90: $439-453$

Cowen RK, Hare JA, Fahay MP (1993) Beyond hydrography: can physical processes explain larval fish assemblages within the Middle Atlantic Bight. Bull Mar Sci 53: $567-587$

Fahay MP (1974) Occurrence of silver hake, Merluccius bilinearis, eggs and larvae along the middle Atlantic continental shelf during 1966. Fish Bull US 72:813-834

Gibson RN (1994) Impact of habitat quality and quantity on the recruitment of juvenile flatfishes. Neth J Sea Res 32: $191-206$

Hare JA, Cowen RK (1995) Effect of age, growth rate, and ontogeny on the otolith size-fish size relationship in bluefish, Pomatomus saltitrix, and the implications for backcalculation of size in fish early life history stages. Can J Fish Aquat Sci 52:1909-1922

Houde ED (1987) Fish early life dynamics and recruitment variability. Am Fish Soc Symp 2:17-29

Hovenkamp F (1990) Growth differences in larval plaice Pleuronectes platessa in the Southern Bight of the North Sea as indicated by otolith increments and RNA/DNA ratios. Mar Ecol Prog Ser 58:205-215

Jenkins GP, Shaw M, Stewart BD (1993) Spatial variation in food-limited growth of juvenile greenback flounder, Rhombosolea tapirina: evidence from otolith daily increments and otolith scaling. Can J Fish Aquat Sci 50: $2558-2567$

Kendall AW, Naplin NA (1981) Diel-depth distribution of summer ichthyoplankton in the Middle Atlantic Bight. Fish Bull US 79:705-726
Koeller PA, Coates-Markle L, Neilson JD (1989) Feeding ecology of juvenile (Age-0) silver hake (Merluccius bilinearis) on the Scotian Shelf. Can J Fish Aquat Sci 46:1762-1768

Lough RG, Valentine PC, Potter DC, Auditore PJ, Bolz GR, Neilson JD, Perry RI (1989) Ecology and distribution of juvenile cod and haddock in relation to sediment type and bottom currents on eastern Georges Bank. Mar Ecol Prog Ser 56:1-12

MacCall AD (1990) Dynamic geography of marine fish populations. Washington Sea Grant Program. University of Washington Press, Seattle

MacDonald PDM, Pitcher TJ (1979) Age-groups from size-frequency data: a versatile and efficient method of analyzing distribution mixtures. J Fish Res Board Can 36:987-1001

NEFSC (Northeast Fisheries Science Center) (1993) Status of fishery resources off the Northeastern United States NOAA Technical Memorandum NMFS-F/NEC 101. Northeast Fisheries Science Center, Woods Hole, MA, p 1-140

Neill WH, Miller JM, Van der Veer HW, Winemiller KO (1994) Ecophysiology of marine fish recruitment; a conceptual framework for understanding interannual variability. Neth J Sea Res 32(2):135-152

Nishimura A, Yamada J (1984) Age and growth of larval and juvenile walleye pollock, Theragra chalcogramma (Pallas), as determined by otolith daily growth increments. J Exp Mar Biol Ecol 82(2-3):191-205

Panella G (1971) Fish otoliths: daily growth layers and periodical patterns. Science 173:1124-1127

Pearce JB, Radosh DJ, Caracciolo JV, Steimle FV Jr (eds) (1981) Benthic fauna. MESA New York Bight Atlas Monograph 14. New York Sea Grant Institute, Albany, NY, p $1-79$

Sherman K, Smith W, Morse W, Berman M, Green J, Ejsymont L. (1984) Spawning strategies of fishes in relation to circulation, phytoplankton production, and pulses in zooplankton off the northeastern United States. Mar Ecol Prog Ser $18: 1-19$

Sissenwine MP (1984) Why do fish populations vary? In: May RM (ed) Exploitation of marine communities. Dhlem Konferenzen Springer-Verlag, New York, p 59-94

Sogard SM (1991) Interpretation of otolith microstructure in juvenile winter flounder (Pseudopleuronectes americanus): ontogenetic development, daily increment validation, and somatic growth relationships. Can J Fish Aquat Sci 48:1862-1871

Sogard SM (1992) Variability in growth rates of juvenile fishes in different estuarine habitats. Mar Ecol Prog Ser 85: $35-53$

Sponaugle S, Cowen RK (1994) Larval durations and recruitment patterns of two Caribbean gobies (Gobiidae): contrasting early life histories in demersal spawners. Mar Biol $120: 133-143$

Steves BP, Cowen RK, Malchoff M (1999) Settlement and nursery habitats for demersal fishes on the continental shelf of the New York Bight. Fish Bull US 98:167-188

Suthers IM, Frank KT, Campana SE (1989) Spatial comparison of recent growth in postlarval Atlantic cod (Gadus morhua) off southwestern Nova Scotia: inferior growth in a presumed nursery area. Can J Fish Aquat Res 46(Suppl 1):113-124

Tanaka M, Goto T, Tomiyama M, Sudo H, Azuma M (1989) Lunar-phased immigration and settlement of metamorphosing Japanese flounder larvae into a nearshore nursery ground. Rapp PV Réun Cons Int Explor Mer 191 $303-310$

Thorrold SR, Shenker JM, Maddox ED, Mojica R JI, Wishinski E (1994) Larval supply of shorefishes to nursery habitats 
around Lee Stocking Island, Bahamas. II. Lunar and oceanographic influences. Mar Biol 118:567-578

Toole CL, Markle D, Harris P (1993) Relationships between otolith microstructure, microchemistry, and early life history events in Dover sole, Microstomus pacificus. Fish Bull US $91: 732-753$

Toole CL, Markle DF, Donohue CJ (1997) Settlement timing, distribution, and abundance of Dover sole (Microstomus

Editorial responsibility: Otto Kinne (Editor),

Oldendorf/Luhe, Germany pacificus) on an outer continental shelf nursery area. Can J Fish Aquat Sci 54:531-542

Woodbury D, Hollowed $A B$, Pearce JA (1995) Interannual variation in growth rates and back-calculated spawn dates of juvenile Pacific hake, Merluccius productus. In: Secor DH, Dean JM, Campana SE (eds) Recent developments in fish otolith research. Univ of South Carolina Press, Columbia, SC, p 481-496

Submitted: February 17, 1999; Accepted: October 28, 1999 Proofs received from author(s): March 21, 2000 